\title{
Associations between model-predicted rivaroxaban exposure and patient characteristics and efficacy and safety outcomes in patients with non-valvular atrial fibrillation
}

\author{
Liping Zhang ${ }^{1,9}$ - Xiaoyu Yan ${ }^{1} \cdot$ Keith A. A. Fox ${ }^{2} \cdot$ Stefan Willmann ${ }^{3} \cdot$ Partha Nandy $^{1} \cdot$ Scott D. Berkowitz ${ }^{4}$. \\ Anne Hermanowski-Vosatka ${ }^{1}$. Jeffrey I. Weitz ${ }^{5} \cdot$ Alexander Solms $^{6} \cdot$ Stephan Schmidt $^{7} \cdot$ Manesh Patel $^{8} \cdot$ Gary Peters $^{1}$
}

Published online: 23 April 2020

(c) The Author(s) 2020

\begin{abstract}
Rivaroxaban exposure and patient characteristics may affect the rivaroxaban benefit-risk balance. This study aimed to quantify associations between model-predicted rivaroxaban exposure and patient characteristics and efficacy and safety outcomes in patients with non-valvular atrial fibrillation (NVAF), using data from the phase 3 ROCKET AF trial (NCT00403767). In ROCKET AF, 14,264 patients with NVAF were randomized to rivaroxaban (20 mg once daily [OD], or $15 \mathrm{mg}$ OD if creatinine clearance was 30-49 $\mathrm{mL} / \mathrm{min}$ ) or dose-adjusted warfarin (median follow-up: 707 days); rivaroxaban plasma concentration was measured in a subset of 161 patients. In this post hoc exposure-response analysis, a multivariate Cox model was used to correlate individual predicted rivaroxaban exposures and patient characteristics with time-to-event efficacy and safety outcomes in 7061 and 7111 patients, respectively. There was no significant association between model-predicted rivaroxaban trough plasma concentration $\left(\mathrm{C}_{\text {trough }}\right)$ and efficacy outcomes. Creatinine clearance and history of stroke were significantly associated with efficacy outcomes. $\mathrm{C}_{\text {trough }}$ was significantly associated with the composite of major or non-major clinically relevant (NMCR) bleeding (hazard ratio [95th percentile vs. median]: 1.26 [95\% confidence interval 1.13-1.40]) but not with major bleeding alone. The exposure-response relationship for major or NMCR bleeding was shallow with no clear threshold for an acceleration in risk. History of gastrointestinal bleeding had a greater influence on safety outcomes than $\mathrm{C}_{\text {trough }}$. These results support fixed rivaroxaban $15 \mathrm{mg}$ and $20 \mathrm{mg}$ OD dosages in NVAF. Therapeutic drug monitoring is unlikely to offer clinical benefits in this indication beyond evaluation of patient characteristics.
\end{abstract}

Keywords Atrial fibrillation $\cdot$ Drug monitoring $\cdot$ Pharmacokinetics $\cdot$ Randomized controlled trial $\cdot$ Rivaroxaban

Electronic supplementary material The online version of this article (https://doi.org/10.1007/s11239-020-02077-9) contains supplementary material, which is available to authorized users.

Liping Zhang

LZhang11@ITS.JNJ.com

1 Janssen Research \& Development, LLC, Raritan, NJ, USA

2 Centre for Cardiovascular Science, The University of Edinburgh, Edinburgh, UK

3 Clinical Pharmacometrics, Bayer AG, Wuppertal, Germany

4 Bayer U.S., LLC, Research \& Development, Pharmaceuticals, Whippany, NJ, USA

5 Thrombosis \& Atherosclerosis Research Institute, McMaster University, Hamilton, ON, Canada
6 Clinical Pharmacometrics, Bayer AG, Berlin, Germany

7 Center for Pharmacometrics and Systems Pharmacology, Department of Pharmaceutics, College of Pharmacy, University of Florida, Orlando, FL, USA

8 Duke Clinical Research Institute, Durham, NC, USA

9 Clinical Pharmacology and Pharmacometrics, Janssen Research \& Development, LLC, 920 Route 202, Raritan, NJ 08869, USA 


\section{Highlights}

- In these post hoc exposure-response analyses conducted for the rivaroxaban arm of ROCKET AF, there was no significant relationship between predicted rivaroxaban exposure and efficacy outcomes.

- There was a significant relationship between rivaroxaban exposure and the incidence of major or non-major clinically relevant (NMCR) bleeding, but the association between exposure and the risk of major bleeding was not statistically significant.

- The increase in the risk of NMCR bleeding with increasing exposures was gradual and the exposure-response relationship shallow, with no clear threshold for acceleration of bleeding risk.

- Patient characteristics had a greater impact on efficacy outcomes and the risk of major bleeding, and a similar or greater influence on the risk of major or NMCR bleeding, compared with rivaroxaban exposure.

- These findings suggest monitoring rivaroxaban levels is unlikely to offer benefits over evaluating patient factors.

\section{Introduction}

Rivaroxaban, an oral direct factor Xa inhibitor, is approved for the prevention of stroke and systemic embolism (SE) in adults with non-valvular atrial fibrillation (NVAF) with one or more risk factors (e.g., prior stroke) [1], based on the phase 3, randomized, controlled trial ROCKET AF (NCT00403767) [2]. In ROCKET AF, rivaroxaban (20 mg once daily [OD], or $15 \mathrm{mg}$ OD if creatinine clearance $[\mathrm{CrCl}]$ was $30-49 \mathrm{~mL} / \mathrm{min}$ ) was non-inferior to dose-adjusted warfarin for the prevention of stroke or SE, and similar with respect to the risk of major bleeding or a composite of major or non-major clinically relevant (NMCR) bleeding.

Advanced age and impaired renal function are associated with increased rivaroxaban exposure [1] and are also independent risk factors for NVAF-related thromboembolism and for major bleeding events in anticoagulant-treated patients [3-6]. It has been proposed that therapeutic drug monitoring (i.e., plasma concentration-based dose adjustment) may help guide anticoagulant dosing for individual patients. This post hoc exposure-response analysis aimed to explore this possibility and to quantify the associations between predicted rivaroxaban exposures, patient characteristics and clinical outcomes in patients with NVAF using data from ROCKET AF.

\section{Methods}

\section{Study design}

Full details of the methodology and ethical conduct of the ROCKET AF study have been reported previously [2, 7]. Briefly, 14,264 patients with NVAF were randomized to receive rivaroxaban $(20 \mathrm{mg}$ OD, or $15 \mathrm{mg}$ OD in patients with a $\mathrm{CrCl}$ of $30-49 \mathrm{~mL} / \mathrm{min}$ ) or dose-adjusted warfarin (median follow-up: 707 days; median duration of treatment: 590 days) (Table 1) [2,7].

The efficacy outcomes evaluated in this exposure-response analysis were a composite of ischemic stroke or non-central nervous system (non-CNS) SE, and a composite of ischemic stroke, non-CNS SE or all-cause death. Major bleeding events and the composite endpoint of major or NMCR bleeding events were evaluated as safety outcomes (Table 1).

\section{Patient characteristics}

Patient characteristics for potential inclusion in the exposure-response evaluation were identified a priori based on a review of the literature [8-11] and experiences in ROCKET AF $[2,12,13]$. The variables were categorical in nature or grouped categorically to aid clinical interpretation.

\section{Rivaroxaban exposure predictions}

An integrated population pharmacokinetics (popPK) model was developed as previously described [14]. The model used pooled rivaroxaban pharmacokinetic data from a subset of 161 patients for whom rivaroxaban exposure was measured in ROCKET AF, and from patients in six phase 2 trials of rivaroxaban in which a wide range of rivaroxaban doses were evaluated [14]. Individual steady-state rivaroxaban exposure metrics (including area under the plasma concentration-time curve from time 0 to $24 \mathrm{~h}$ [ $\left.\mathrm{AUC}_{0-24}\right]$, maximum plasma concentration $\left[\mathrm{C}_{\max }\right]$ and trough plasma concentration $\left.\left[\mathrm{C}_{\text {trough }}\right]\right)$ for each patient were predicted based on individual patient characteristics (age, weight, renal function measured as rate of $\mathrm{CrCl}$, and sex) and rivaroxaban dose.

Using patient characteristics alone to predict individual exposure might not appropriately reflect the variability expected. Therefore, prothrombin time (PT) measurements, collected from ROCKET AF participants at weeks 12 and 24, were used to derive rivaroxaban $\mathrm{AUC}_{0-24}, \mathrm{C}_{\max }$ and $\mathrm{C}_{\text {trough }}$, based on the linear relationship between plasma concentration and PT determined using a thromboplastin reagent sensitive to the anticoagulant effects of rivaroxaban [15]. This adjustment enhanced precision in the exposure 
Table 1 Description of ROCKET AF and outcomes and event rates for the exposure-response analyses

\begin{tabular}{|c|c|}
\hline & ROCKET AF [2] \\
\hline Design & $\begin{array}{l}\text { Multicenter, randomized, double-blind, double-dummy, event-driven trial conducted at } 1178 \text { par- } \\
\text { ticipating sites in } 45 \text { countries }\end{array}$ \\
\hline Population & $\begin{array}{l}\text { Patients with NVAF, as documented on electrocardiography, who were at moderate-to-high risk of } \\
\text { stroke }\end{array}$ \\
\hline Total number of patients randomized & 14,264 \\
\hline Pertinent exclusion criteria & $\begin{array}{l}\text { Hemodynamically significant mitral valve stenosis, planned electrical or pharmacological cardio- } \\
\text { version, active internal bleeding, history of, or a condition associated with, increased bleeding } \\
\text { risk }\end{array}$ \\
\hline Rivaroxaban dose and regimen & $20 \mathrm{mg}$ OD, or $15 \mathrm{mg}$ OD in patients with a $\mathrm{CrCl}$ of $30-49 \mathrm{~mL} / \mathrm{min}$ \\
\hline Comparator dose and regimen & Adjusted-dose warfarin (target INR, 2.0-3.0) \\
\hline Other treatments & Concomitant use of aspirin was allowed \\
\hline Median follow-up & 707 days \\
\hline Median treatment duration & 590 days \\
\hline Total number of patients for ER analysis & $\begin{array}{l}7061 \text { (efficacy) } \\
7111 \text { (safety) }\end{array}$ \\
\hline Efficacy outcomes for ER analysis: n (\%) & $\begin{array}{l}\text { 1. Ischemic stroke or non-CNS SE: } 154 \text { (2.2) } \\
\text { 2. Ischemic stroke, non-CNS SE or all-cause death: } 357 \text { (5.1) }\end{array}$ \\
\hline Safety outcomes for ER analysis: $\mathrm{n}(\%)$ & $\begin{array}{l}\text { 1. Major bleeding }{ }^{\mathrm{a}}: 395(5.6) \\
\text { 2. Major or NMCR bleeding }: 1457 \text { (20.7) }\end{array}$ \\
\hline
\end{tabular}

$C N S$ central nervous system, $C r C l$, creatinine clearance, $E R$ exposure-response, $I N R$ international normalized ratio, $N M C R$ non-major clinically relevant, $N V A F$ non-valvular atrial fibrillation, $O D$ once daily, $S E$ systemic embolism

${ }^{a}$ Major bleeding was defined, in accordance with International Society on Thrombosis and Haemostasis criteria, as the following: overt bleeding associated with a decrease in hemoglobin level of $\geq 2 \mathrm{~g} / \mathrm{dL}$ or leading to a transfusion of $\geq 2$ units of packed red blood cells or whole blood; bleeding in a critical site; or bleeding contributing to death [24]

${ }^{b}$ NMCR bleeding was defined as overt bleeding that did not meet the criteria for major bleeding but that was associated with medical intervention, unscheduled contact with a physician, interruption or discontinuation of study drug, or discomfort or impairment of activities of daily life [2]

predictions and was applied to 5681 patients in ROCKET $\mathrm{AF}$, including the 161 patients with available rivaroxaban exposure measurements [15].

Exposure-efficacy analyses included patients who received at least one dose of rivaroxaban, were followed for events while receiving rivaroxaban or within 2 days after discontinuation, and had available efficacy outcome data. Exposure-safety analyses included patients who received at least one dose of rivaroxaban and were followed for events while receiving rivaroxaban or within 2 days after discontinuation. Measures of exposure in these analyses were predicted based on the popPK model, patient characteristics and dose, with or without PT adjustment for over 7000 patients.

\section{Regression analyses}

Relationships between rivaroxaban exposure metrics, patient characteristics and the efficacy and safety outcomes were assessed using Cox proportional regression analysis, as described in the supplemental material. The hazard ratios (HRs) generated for the variables using the final models for each outcome were displayed in forest plots. The reference category was the category most commonly observed for the variable, except for geographic region for which Western Europe was set as the reference. The final models were used to simulate the probability of efficacy or safety events at 1 year versus predicted exposure in a typical patient population (i.e., with individual patient characteristics set to reference values).

\section{Results}

\section{Patient characteristics}

Supplemental Table 1 shows the characteristics of patients selected for evaluation in the efficacy $(\mathrm{n}=7061)$ and safety $(\mathrm{n}=7111)$ populations. Approximately $38 \%$ of patients were $>75$ years of age, $40 \%$ were female, $81 \%$ had persistent atrial fibrillation (AF) and $43 \%$ had a $\mathrm{CHADS}_{2}$ score of 3. Baseline antiplatelet and non-steroidal anti-inflammatory drug (NSAID) use and prior vitamin $\mathrm{K}$ antagonist use were reported in $40 \%, 4 \%$ and $62 \%$ of patients, respectively. Histories of stroke, transient ischemic attack and SE were present in 34\%, 22\% and 4\% of patients, respectively. Baseline $\mathrm{CrCl}$ was $<50 \mathrm{~mL} / \mathrm{min}$ in $21 \%$ of patients. 


\section{Rivaroxaban exposure predictions and event rates}

Predicted $\mathrm{C}_{\text {trough }}$ showed larger between-patient variability than predicted $\mathrm{AUC}_{0-24}$ or $\mathrm{C}_{\max }$ (Supplemental Table 2). The exposure predictions were all highly correlated $(>0.85)$ within a given individual. The observed event rates for efficacy and safety outcomes are summarized in Table 1.

$\mathrm{C}_{\text {trough }}$ was the exposure metric most strongly associated with the likelihood of both efficacy and safety events, as evident from the lowest Akaike information criterion (AIC) value, and was selected for investigation for both analyses, as described in the supplemental material.

\section{Regression analyses}

The results of the final exposure-response models are shown in Table 2 and Supplemental Table 3.

\section{Exposure-efficacy analysis}

There was no apparent trend between $\mathrm{C}_{\text {trough }}$ quartiles and the composite efficacy outcomes (Fig. 1a, b).

There was also no significant association between $\mathrm{C}_{\text {trough }}$ and the outcome in the final model for ischemic stroke or non-CNS SE; the HRs associated with $\mathrm{C}_{\text {trough }}$ in the 5th and 95th percentiles versus the median were 1.02 (95\% confidence interval [CI] 0.89-1.18) and 0.94 (95\% CI 0.65-1.35), respectively (Fig. 2a). Of the variables included in the model, $\mathrm{CrCl}$ and history of stroke showed a significant association with the outcome; there was no significant association with age (Fig. 2a, Supplemental Table 3).

In the final model for ischemic stroke, non-CNS SE or all-cause death, there were no significant associations between either $\mathrm{C}_{\text {trough }}$ or age and the outcome; significant associations were evident for $\mathrm{CrCl}$, geographic region and histories of stroke, myocardial infarction (MI) and heart failure (Fig. 2b, Supplemental Table 3). Histories of stroke and MI had an impact similar to or greater than $\mathrm{CrCl}$, with HRs of 1.56 (95\% CI 1.25-1.94) and 1.84 (95\% CI 1.44-2.35), respectively.

There was a small decrease in expected HR for ischemic stroke or non-CNS SE with increasing predicted $\mathrm{C}_{\text {trough }}$ values (Fig. 3a). The association was relatively flat between the HR for ischemic stroke, non-CNS SE or all-cause death and predicted $\mathrm{C}_{\text {trough }}$ values (Fig. 3a).

\section{Exposure-safety analysis}

The cumulative event rates for major bleeding (Fig. 1c) and for the composite of major or NMCR bleeding (Fig. 1d) increased with increasing rivaroxaban $\mathrm{C}_{\text {trough }}$.

In the final model for major bleeding, the HRs associated with $\mathrm{C}_{\text {trough }}$ in the 5 th and 95 th percentiles (vs. the median) were 0.92 (95\% CI 0.85-0.99) and 1.25 (95\% CI $1.03-1.51)$, respectively; the association between $\mathrm{C}_{\text {trough }}$ and major bleeding risk was not statistically significant (Fig. 2c). Age ( $>75$ years vs. $65-75$ years) was significantly associated with major bleeding (Fig. 2c, Supplemental Table 3). Patients in North America versus Western Europe had a higher risk of major bleeding, and the risk of major bleeding was higher in patients with versus without baseline use of NSAIDs or aspirin, a history of gastrointestinal (GI) bleeding, and low baseline hemoglobin. $\mathrm{CrCl}$ had no significant impact on major bleeding risk.

For major or NMCR bleeding, the HRs associated with $\mathrm{C}_{\text {trough }}$ in the 5th and 95th percentiles (vs. the median) in the final model were statistically significant $(0.92$ [95\% CI $0.88-0.95]$ and 1.26 [95\% CI 1.13-1.40], respectively; Fig. 2d,

Table 2 Results of the final exposure-response models

\begin{tabular}{|c|c|c|c|c|}
\hline \multirow[t]{2}{*}{ Variables } & \multicolumn{2}{|l|}{ Efficacy } & \multicolumn{2}{|l|}{ Safety } \\
\hline & $\begin{array}{l}\text { Ischemic stroke and } \\
\text { non-CNS SE }\end{array}$ & $\begin{array}{l}\text { Ischemic stroke, non-CNS SE } \\
\text { and all-cause death }\end{array}$ & Major bleeding & Major/NMCR bleeding \\
\hline $\mathrm{Age}^{\mathrm{a}}$ & n.s & n.s & $\mathrm{X}$ & $\mathrm{X}$ \\
\hline $\mathrm{CrCl}^{\mathrm{a}}$ & $\mathrm{X}$ & $\mathrm{X}$ & n.s & n.s \\
\hline Best exposure & n.s & n.s & n.s & $\mathrm{C}_{\text {trough }}$ \\
\hline $\begin{array}{l}\text { Other significant } \\
\text { covariate }\end{array}$ & History of stroke & $\begin{array}{l}\text { History of HF } \\
\text { History of MI } \\
\text { Geographic region } \\
\text { History of stroke }\end{array}$ & $\begin{array}{l}\text { Aspirin use }{ }^{\mathrm{b}} \\
\text { History of GI bleeding } \\
\text { Low hemogloblin }^{\mathrm{b}} \\
\text { NSAID use } \\
\text { Geographic region }\end{array}$ & $\begin{array}{l}\text { Antiplatelet use } \\
\text { History of GI bleeding } \\
\text { Low hemoglobin }^{\mathrm{b}} \\
\text { Geographic region } \\
\text { History of vascular disease }\end{array}$ \\
\hline
\end{tabular}

$C N S$ central nervous system, $C r C l$ creatinine clearance, $C_{\text {trough }}$ trough plasma concentration, $G I$ gastrointestinal, $H F$ heart failure, $M I$ myocardial infarction, $N M C R$ non-major clinically relevant, n.s. not significant, NSAID non-steroidal anti-inflammatory drug, $S E$ systemic embolism

${ }^{\text {a}}$ Forced input variables

${ }^{\mathrm{b}}$ At baseline

$\mathrm{X}$ denotes statistically significant exposure-response relationship $(\mathrm{p} \leq 0.01)$ 

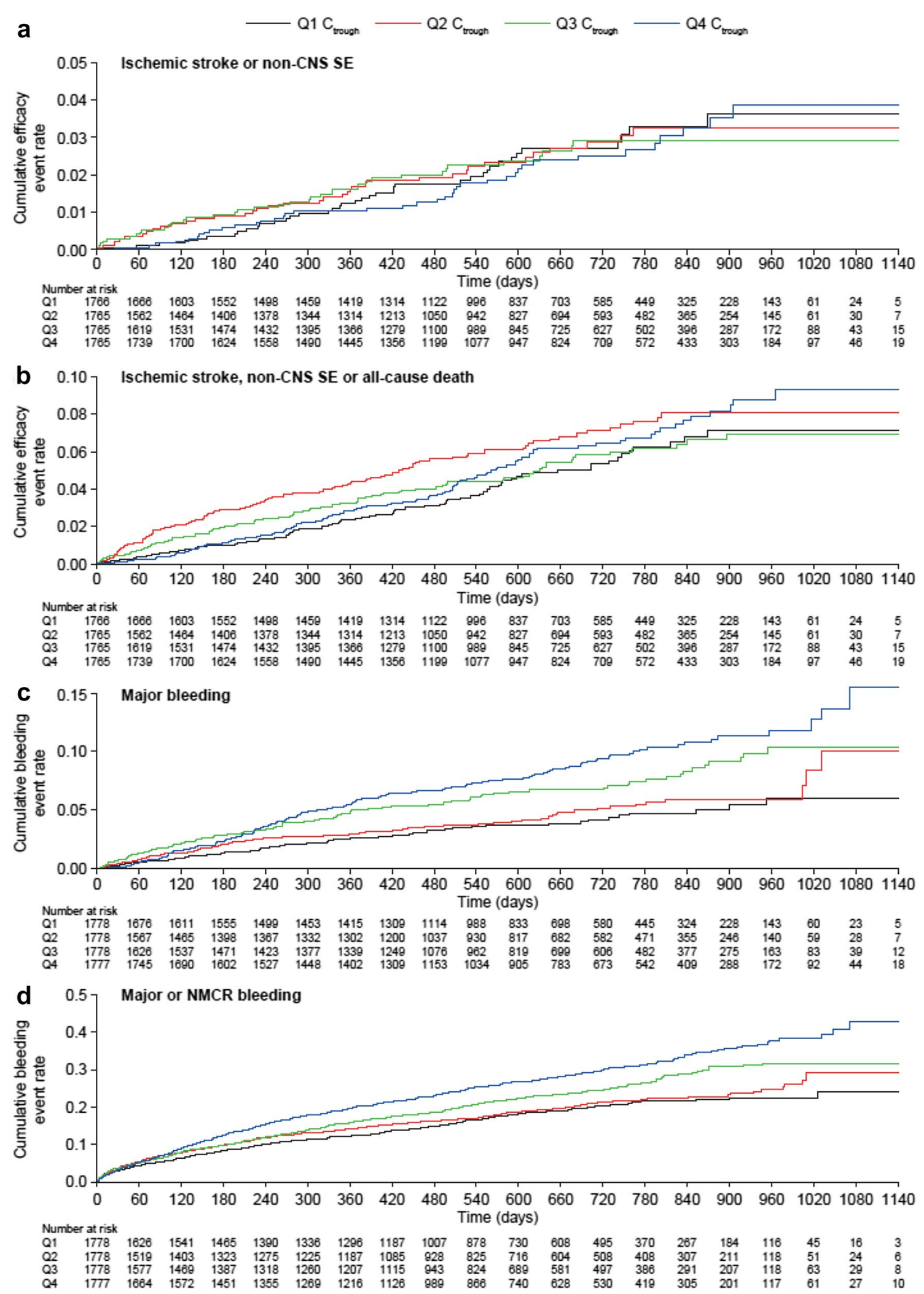

Fig. 1 Kaplan-Meier plots of the cumulative event rates for the following outcomes versus predicted steady-state $\mathrm{C}_{\text {trough }}$ : composite efficacy outcomes of (a) ischemic stroke or non-CNS SE and (b) ischemic stroke, non-CNS SE or all-cause death; and the safety out- comes of (c) major bleeding and (d) major or NMCR bleeding. CNS central nervous system, $C_{\text {trough }}$ trough plasma concentration, NMCR non-major clinically relevant, $Q$ quartile, $S E$ systemic embolism 


\section{a Ischemic stroke or non-CNS SE}

$\mathrm{HR}(95 \% \mathrm{Cl})$

\begin{tabular}{|c|c|c|c|c|}
\hline $\begin{array}{l}\text { Rivaroxaban } \\
\mathrm{C}_{\text {rougn }}\end{array}$ & $\begin{array}{l}5 \% \\
\text { Median } \\
95 \%\end{array}$ & & - & $\begin{array}{l}1.02(0.89-1.18) \\
1.00 \\
0.94(0.65-1.35)\end{array}$ \\
\hline Age, years & $\begin{array}{l}65-75 \\
<65 \\
>75\end{array}$ & $\longrightarrow$ & + & $\begin{array}{l}1.00 \\
0.88(0.56-1.37) \\
0.78(0.53-1.13)\end{array}$ \\
\hline $\mathrm{CrCl}, \mathrm{mL} / \mathrm{min}$ & $\begin{array}{l}50-80 \\
<50 \\
>80\end{array}$ & & & $\begin{array}{l}1.00 \\
1.60(1.09-2.36) \\
0.70(0.46-1.08)\end{array}$ \\
\hline \multirow[t]{2}{*}{$\begin{array}{l}\text { History } \\
\text { of stroke }\end{array}$} & $\begin{array}{l}\text { No } \\
\text { Yes }\end{array}$ & & $\longrightarrow$ & $\begin{array}{l}1.00 \\
2.01(1.46-2.77)\end{array}$ \\
\hline & 0.2 & 0.5 & 1 & 5 \\
\hline
\end{tabular}

\section{Major bleeding}

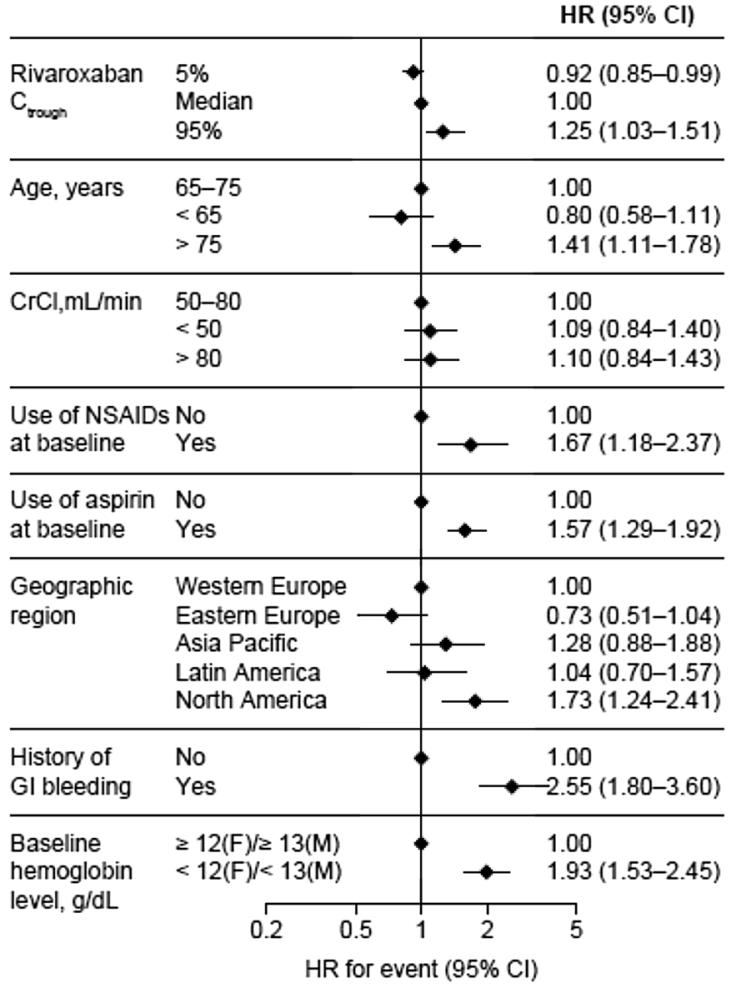

Fig. 2 HRs for the composite efficacy outcomes of (a) ischemic stroke or non-CNS SE and (b) ischemic stroke, non-CNS SE or allcause death, based on results of the final model; and HRs for the safety outcomes of (c) major bleeding and (d) major or NMCR bleeding, based on results of the final model. $C I$ confidence interval, $C N S$ b Ischemic stroke, non-CNS SE or all-cause death

$\mathrm{HR}(95 \% \mathrm{Cl})$

\begin{tabular}{|c|c|c|}
\hline $\begin{array}{l}\text { Rivaroxaban } \\
\text { C troush }^{\text {ton }}\end{array}$ & $\begin{array}{l}5 \% \\
\text { Median } \\
95 \%\end{array}$ & $\begin{array}{l}0.99(0.91-1.08) \\
1.00 \\
1.03(0.81-1.30)\end{array}$ \\
\hline Age, years & $\begin{array}{l}65-75 \\
<65 \\
>75\end{array}$ & $\begin{array}{l}1.00 \\
0.97(0.72-1.31) \\
0.94(0.73-1.21)\end{array}$ \\
\hline $\mathrm{CrCl}, \mathrm{mL} / \mathrm{min}$ & $\begin{array}{l}50-80 \\
<50 \\
>80\end{array}$ & $\begin{array}{ll} & 1.00 \\
\bullet & 1.56(1.21-2.01) \\
& 0.75(0.56-1.00)\end{array}$ \\
\hline $\begin{array}{l}\text { Geographic } \\
\text { region }\end{array}$ & $\begin{array}{l}\text { Western Europe } \\
\text { Eastern Europe } \\
\text { Asia Pacific } \\
\text { Latin America } \\
\text { North America }\end{array}$ & $\begin{array}{ll} & 1.00 \\
-\quad 0.86(0.61-1.20) \\
-\quad 0.99(0.67-1.46) \\
1.38(0.95-2.00) \\
0.67(0.45-1.00)\end{array}$ \\
\hline $\begin{array}{l}\text { History } \\
\text { of stroke }\end{array}$ & $\begin{array}{l}\text { No } \\
\text { Yes }\end{array}$ & $\begin{aligned} & 1.00 \\
- & 1.56(1.25-1.94)\end{aligned}$ \\
\hline History of MI & $\begin{array}{l}\text { No } \\
\text { Yes }\end{array}$ & $\begin{array}{l}1.00 \\
\longrightarrow-1.84(1.44-2.35)\end{array}$ \\
\hline $\begin{array}{l}\text { History of } \\
\text { heart failure }\end{array}$ & $\begin{array}{l}\text { Yes } \\
\text { No }\end{array}$ & $\begin{array}{l}1.00 \\
0.61(0.47-0.78)\end{array}$ \\
\hline & 0.2 & 5 \\
\hline
\end{tabular}

d Major or NMCR bleeding

\begin{tabular}{|c|c|c|c|}
\hline & & & HR $(95 \% \mathrm{Cl})$ \\
\hline $\begin{array}{l}\text { Rivaroxaban } \\
\text { Cltrosh }\end{array}$ & $\begin{array}{l}5 \% \\
\text { Median } \\
95 \%\end{array}$ & $\rightarrow$ & $\begin{array}{l}0.92(0.88-0.95) \\
1.00 \\
1.26(1.13-1.40)\end{array}$ \\
\hline Age, years & $\begin{array}{l}65-75 \\
<65 \\
>75\end{array}$ & $\leftarrow$ & $\begin{array}{l}1.00 \\
0.76(0.65-0.89) \\
1.35(1.19-1.52)\end{array}$ \\
\hline $\mathrm{CrCl}, \mathrm{mL} / \mathrm{min}$ & $\begin{array}{l}50-80 \\
<50 \\
>80\end{array}$ & & $\begin{array}{l}1.00 \\
0.93(0.82-1.07) \\
1.03(0.90-1.19)\end{array}$ \\
\hline $\begin{array}{l}\text { Use of anti- } \\
\text { platelets } \\
\text { at baseline }\end{array}$ & $\begin{array}{l}\text { No } \\
\text { Yes }\end{array}$ & $\rightarrow$ & $\begin{array}{l}1.00 \\
1.27(1.15-1.41)\end{array}$ \\
\hline $\begin{array}{l}\text { Geographic } \\
\text { region }\end{array}$ & $\begin{array}{l}\text { Western Europe } \\
\text { Eastern Europe -- } \\
\text { Asia Pacific } \\
\text { Latin America } \\
\text { North America }\end{array}$ & 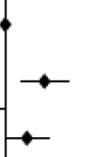 & $\begin{array}{l}1.00 \\
0.64(0.54-0.76) \\
1.38(1.15-1.65) \\
0.83(0.68-1.02) \\
1.20(1.02-1.42)\end{array}$ \\
\hline $\begin{array}{l}\text { History of } \\
\text { GI bleeding }\end{array}$ & $\begin{array}{l}\text { No } \\
\text { Yes }\end{array}$ & $\rightarrow$ & $\begin{array}{l}1.00 \\
1.47(1.17-1.84)\end{array}$ \\
\hline $\begin{array}{l}\text { History of } \\
\text { vascular } \\
\text { disease }\end{array}$ & $\begin{array}{l}\text { No } \\
\text { Yes }\end{array}$ & $\bullet$ & $\begin{array}{l}1.00 \\
1.33(1.19-1.49)\end{array}$ \\
\hline \multirow{2}{*}{$\begin{array}{l}\text { Baseline } \\
\text { hemoglobin } \\
\text { level, g/dL }\end{array}$} & $\begin{array}{l}\geq 12(F) / \geq 13(M) \\
<12(F) /<13(M)\end{array}$ & $\rightarrow$ & $\begin{array}{l}1.00 \\
1.27(1.11-1.46)\end{array}$ \\
\hline & 0.2 & 2 & 5 \\
\hline
\end{tabular}

central nervous system, $\mathrm{CrCl}$ creatinine clearance, $C_{\text {trough }}$ trough plasma concentration, $F$ female, GI gastrointestinal, $H R$ hazard ratio, $M$ male, $M I$ myocardial infarction, NMCR non-major clinically relevant, NSAID non-steroidal anti-inflammatory drug, $S E$ systemic embolism 

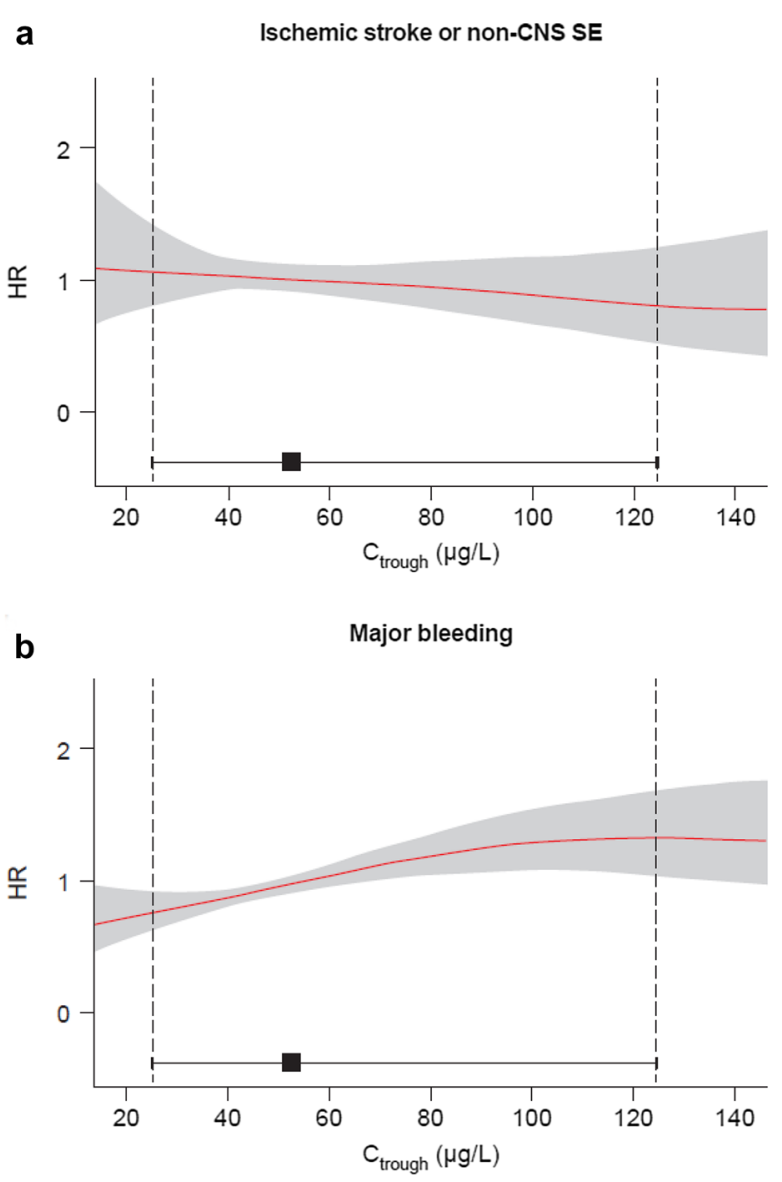

Fig. 3 Expected HRs for (a) efficacy and (b) safety outcomes in a typical patient plotted against the range of predicted $\mathrm{C}_{\text {trough }}$ values. Red lines represent means and shaded areas represent $95 \%$ confidence intervals. Black squares represent median $\mathrm{C}_{\text {trough }}$ and horizontal error bars represent the range between the 5 th and 95 th percentiles

Supplemental Table 3). Overall, history of GI bleeding had the greatest impact on this outcome. Patients aged $>75$ years were more likely to experience major or NMCR bleeding than those aged $65-75$ years, as were patients with versus without low baseline hemoglobin, antiplatelet therapy or a history of vascular disease. The magnitude of the impact of these covariates on the risk of major or NMCR bleeding was similar or greater than that of rivaroxaban $\mathrm{C}_{\text {trough }}$.

For major bleeding, there was a small increase in HR with increasing $\mathrm{C}_{\text {trough }}$ values, which appeared to plateau at $\sim 115 \mu \mathrm{g} / \mathrm{L}$ (Fig. 3b). For major or NMCR bleeding, there was a small increase in $\mathrm{HR}$ over the range of $\mathrm{C}_{\text {trough }}$ values (Fig. 3b).

\section{Expected probability of efficacy or safety events at 1 year of treatment with rivaroxaban}

An increase in $\mathrm{C}_{\text {trough }}$ from the median to the 95th percentile was predicted to increase the probability of having a
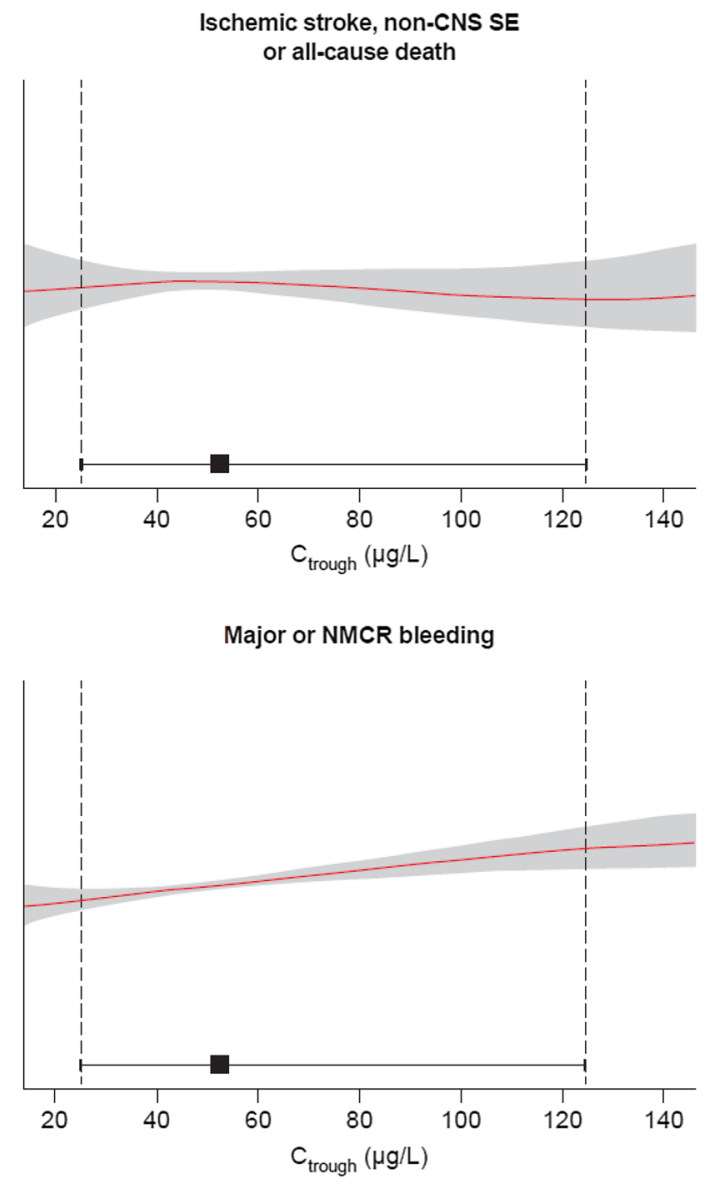

of $\mathrm{C}_{\text {trough }}$. Vertical dashed lines label the 5th and 95th percentiles of $\mathrm{C}_{\text {trough }}$. CNS central nervous system, $C_{\text {trough }}$ trough plasma concentration, $H R$ hazard ratio, $N M C R$ non-major clinically relevant, $S E$ systemic embolism

major bleeding event from $\sim 2.1$ to $\sim 2.8 \%(\mathrm{p}=0.0211)$ and the probability of having a major or NMCR bleeding event from $\sim 12.2$ to $\sim 15.5 \%(\mathrm{p}=0.00002)$ (Supplemental Fig. 1). Having a history of GI bleeding shifted the entire exposure-response curve for major bleeding upwards and appeared to have a greater impact on the probability of major bleeding at 1 year of treatment than any of the predicted changes in rivaroxaban exposure. An increase in $\mathrm{C}_{\text {trough }}$ from the median to the 95th percentile was predicted to increase the probability of having a major bleeding event from $\sim 2.1$ to $\sim 2.8 \%$ in patients without a history of GI bleeding, and from $\sim 5.1$ to $\sim 6.9 \%$ in patients with a history of GI bleeding.

\section{Discussion}

This analysis evaluated rivaroxaban exposure-response relationships in over 7000 patients with NVAF to assess the potential of monitoring drug levels and evaluating patient 
characteristics in optimizing the benefit-risk profile of treatment.

Warfarin, which requires monitoring, has a clear delineation between international normalized ratio values that are associated with maximum efficacy and those that are associated with increased bleeding risk (i.e. a narrow therapeutic window) [16].

In this analysis, rivaroxaban showed no clear lower limit of exposure that resulted in loss of efficacy, indicating a wide therapeutic window for efficacy in the NVAF indication. Several patient characteristics were significantly associated with the composite efficacy outcomes, but the $\mathrm{CHADS}_{2}$ score showed no significant association. A likely explanation is that history of stroke (which showed significant associations with both composite efficacy outcomes) was included as an independent risk factor in the model. Impaired renal function $(\mathrm{CrCl}<50 \mathrm{~mL} / \mathrm{min})$ showed significant associations with both composite efficacy outcomes.

Increasing predicted rivaroxaban $\mathrm{C}_{\text {trough }}$ from the median to the 95th percentile was associated with a significant increase in the risk of major or NMCR bleeding, with a HR of 1.26. The HR for major bleeding was similar (1.25) but the association between $\mathrm{C}_{\text {trough }}$ and the risk of major bleeding was not statistically significant. This may reflect the smaller number of major bleeding events compared with the composite of major or NMCR bleeding events (395 vs. 1475). Thus, the significance of the association between rivaroxaban exposure and major bleeding and the extent to which this contributes to the association between exposure and the composite of major or NMCR bleeding remains uncertain. However, the present analysis does show that the exposure-response relationships for both major bleeding and the composite of major or NMCR bleeding were shallow, with a gradual increase in bleeding risk across a wide range of predicted exposures and no clear threshold of exposure above which the increase in bleeding risk accelerated. The expected increase in the HR of the composite of major or NMCR bleeding, and possibly major bleeding, is therefore small relative to the change in rivaroxaban plasma concentration, which means that any potential gain from measuring rivaroxaban levels and forcing a change in dose would be limited. The CIs around the 1-year estimates of bleeding event rates were wide for any given rivaroxaban concentration and overlapped within the 5th and 95th percentiles of exposure. Taken together, these results suggest that therapeutic drug monitoring would be of limited benefit in patients with NVAF receiving rivaroxaban under the prescribed regimen.

Our analysis identified age, NSAID or aspirin use, history of GI bleeding and low baseline hemoglobin as the components of the HAS-BLED and other bleeding scores $[4,8,11]$, which were statistically significant risk factors for major bleeding. These patient characteristics therefore appeared to be more important determinants of risk than rivaroxaban exposure. The increased risk of major bleeding in North American patients compared with those from Western Europe observed in this analysis may be due to ascertainment bias or other confounding factors, such as comorbidities [12]. For major or NMCR bleeding, patient characteristics such as history of GI bleeding and age were statistically significant risk factors, with an impact similar to or greater than rivaroxaban exposure. For example, increasing rivaroxaban $\mathrm{C}_{\text {trough }}$ from the median to the 95 th percentile (from 52.55 to $124.13 \mu \mathrm{g} / \mathrm{L}$ ) increased the risk of the composite of major or NMCR bleeding by $26 \%$, whereas having a history of GI bleeding increased this risk by $47 \%$.

Similar findings regarding the effects of exposure and patient characteristics on bleeding risk have been reported for edoxaban, another direct factor Xa inhibitor. In separate analyses of phase 2 and phase 3 trial data, there were significant increases in bleeding risk with increasing edoxaban exposure in patients with NVAF $[17,18]$. In contrast to the present results for rivaroxaban, the relationship between edoxaban exposure and bleeding risk was steep over the exposure range [18]. However, edoxaban dose reductions based on patient characteristics in the phase three trial were associated with preservation of efficacy and further reductions in the incidence of major bleeding compared with warfarin (dose reduction vs. no dose reduction; $p$ interaction $\leq 0.023$ ), leading the authors to conclude that the data validate the strategy of tailoring the dose based on clinical factors alone and that such a strategy obviates the need for drug monitoring [19]. The significant variability in exposures in both the edoxaban and dabigatran trials and thus the potential difficulty in selecting threshold drug concentrations for guiding dose changes was also highlighted $[18,19]$.

The dosage of rivaroxaban in ROCKET AF was tailored based on renal function ( $20 \mathrm{mg}$ OD reduced to $15 \mathrm{mg}$ OD in patients with a $\mathrm{CrCl}$ of $30-49 \mathrm{~mL} / \mathrm{min}$ ) and these dosages were subsequently approved for the NVAF indication $[2,20]$. Renal function is also a key consideration in decision-making regarding peri-procedural management of rivaroxaban therapy [21]. While monitoring of coagulation and plasma drug concentrations has been proposed in some patients for guiding pre- and peri-procedural management of direct oral anticoagulants [22], expert consensus from the American College of Cardiology (ACC) focuses on the importance of patient and procedural risk factors. The ACC recommends that patient risk factors for bleeding followed by bleeding risk of the procedure be considered for the decision on whether or not to interrupt therapy, and that the specific drug and level of renal function then be used to guide the timing and duration of interruption to therapy [21]. Results from the present analysis support the central role of patient characteristics in decision-making processes regarding bleeding 
risk with rivaroxaban and the limited likely value of adding drug monitoring into management pathways.

Limitations of this analysis include the paucity of direct rivaroxaban plasma concentration measurements in ROCKET AF, although this was partially offset by the PT adjustment in some patients $[14,15]$. The predicted $\mathrm{C}_{\text {trough }}$ values showed moderate between-patient variability (coefficient of variation: 54\%) and were consistent with the previously published ROCKET AF popPK model [23]. In addition, because ROCKET AF was not designed to evaluate exposure-response relationships, the current analysis may have been underpowered to detect statistically significant differences for some outcomes. Finally, the exposure-response analysis included baseline use of antiplatelet agents and NSAIDs but did not evaluate the impact of their continued use during follow-up.

\section{Conclusions}

These results support fixed rivaroxaban $15 \mathrm{mg}$ and $20 \mathrm{mg}$ OD dosages in patients with NVAF and suggest therapeutic drug monitoring is unlikely to offer clinical benefits in this indication beyond evaluation of patient characteristics.

Acknowledgements This work was conducted at Bayer AG, Bayer U.S., LLC, and Janssen Research \& Development, LLC. E. Bolton of Oxford PharmaGenesis, Oxford, UK, provided medical writing support, which was funded by Bayer AG, Berlin, Germany. The authors would like to thank D. Garmann (Bayer AG, Wuppertal, Germany), T. Spiro (Bayer U.S., LLC, Whippany, NJ, USA), C. Nessel, A. Sharma and M. Samtani (Janssen Research \& Development, LLC, Raritan, NJ, USA), J. Piccini (Duke Clinical Research Institute, Durham, NC, USA) and R. C. Becker (University of Cincinnati College of Medicine, Cincinnati, OH, USA) for their input and helpful comments during the preparation of the manuscript.

Author contributions L. Zhang, X. Yan, S. Willmann, P. Nandy, A. Hermanowski-Vosatka, A. Solms and G. Peters contributed to the concept and design of this analysis, analyzed and interpreted the data and critically revised the manuscript. K. A. A. Fox and M. Patel contributed to the design of the ROCKET AF trial and critically revised the manuscript. S. D. Berkowitz contributed to the concept and design of this analysis and to the operation of the ROCKET AF trial, analyzed and interpreted the data and critically revised the manuscript. J. I. Weitz and S. Schmidt critically reviewed the data analysis and revised the manuscript. All authors approved the final version of the manuscript and accept full responsibility for the work.

\section{Compliance with ethical standards}

Conflict of interest This analysis, including its design, and the collection, analysis and interpretation of data, were funded by Bayer AG, Berlin, Germany, and Janssen Research \& Development, LLC, Raritan, NJ, USA. The writing of the report and decision to submit the work for publication were carried out jointly by the authors, some of whom are employees of Bayer AG and Janssen Research \& Development, LLC. All authors had access to the study data. A. Solms and S. Willmann are employees of Bayer AG; S.D. Berkowitz is an employee of Bayer U.S., LLC This work was conducted within the scope of their employment, and no additional payment was received. L. Zhang, P. Nandy, A. Hermanowski-Vosatka and G. Peters are employees of Janssen Research \& Development, LLC, and own stock in Johnson \& Johnson. This work was conducted within the scope of their employment, and no additional payment was received. X. Yan was an employee of Janssen Research \& Development, LLC, at the time that this work was carried out and owns stock in Johnson \& Johnson. He is currently an employee of The Chinese University of Hong Kong. This work was conducted within the scope of his employment at Janssen Research \& Development, LLC, and no additional payment was received. S. Schmidt is a paid consultant for Bayer AG. K. A. A. Fox has received grants and honoraria relating to this work from Bayer AG and Janssen Research \& Development, LLC, and he has received grants for unrelated work from AstraZeneca and honoraria from Sanofi/Regeneron and Verseon. J. I. Weitz is a consultant for and has received honoraria from Bayer, Boehringer Ingelheim, Bristol-Myers Squibb, Daiichi Sankyo, Ionis, Janssen, Merck, Novartis, Pfizer and Portola. M. Patel has attended advisory boards for AstraZeneca, Bayer and Janssen Research \& Development, LLC, and he has received research funding from AstraZeneca.

Ethical approval All procedures performed in studies involving human participants were in accordance with the ethical standards of the institutional and/or national research committee; details have been published previously $[2,7]$. This article does not contain any studies with animals performed by any of the authors.

Informed consent Informed consent was obtained from all individual participants included in the study; details have been published previously $[2,7]$.

Open Access This article is licensed under a Creative Commons Attribution 4.0 International License, which permits use, sharing, adaptation, distribution and reproduction in any medium or format, as long as you give appropriate credit to the original author(s) and the source, provide a link to the Creative Commons licence, and indicate if changes were made. The images or other third party material in this article are included in the article's Creative Commons licence, unless indicated otherwise in a credit line to the material. If material is not included in the article's Creative Commons licence and your intended use is not permitted by statutory regulation or exceeds the permitted use, you will need to obtain permission directly from the copyright holder. To view a copy of this licence, visit http://creativecommons.org/licenses/by/4.0/.

\section{References}

1. Bayer AG (2018) Rivaroxaban summary of product characteristics. https://www.ema.europa.eu/documents/product-information/ xarelto-epar-product-information_en.pdf. Accessed Feb 2020

2. Patel MR, Mahaffey KW, Garg J, Pan G, Singer DE, Hacke W, Breithardt G, Halperin JL, Hankey GJ, Piccini JP, Becker RC, Nessel CC, Paolini JF, Berkowitz SD, Fox KA, Califf RM, ROCKETAF Investigators (2011) Rivaroxaban versus warfarin in nonvalvular atrial fibrillation. N Engl J Med 365(10):883-891. https ://doi.org/10.1056/NEJMoa1009638

3. Friberg L, Rosenqvist M, Lip GY (2012) Evaluation of risk stratification schemes for ischaemic stroke and bleeding in 182 678 patients with atrial fibrillation: the Swedish Atrial Fibrillation cohort study. Eur Heart J 33(12):1500-1510. https://doi. org/10.1093/eurheartj/ehr488 
4. Hijazi Z, Oldgren J, Lindbäck J, Alexander JH, Connolly SJ, Eikelboom JW, Ezekowitz MD, Held C, Hylek EM, Lopes RD, Siegbahn A, Yusuf S, Granger CB, Wallentin L, ARISTOTLE, and RE-LY Investigators (2016) The novel biomarker-based $\mathrm{ABC}$ (age, biomarkers, clinical history)-bleeding risk score for patients with atrial fibrillation: a derivation and validation study. Lancet 387(10035):2302-2311. https://doi.org/10.1016/S0140 $-6736(16) 00741-8$

5. Albertsen IE, Rasmussen LH, Overvad TF, Graungaard T, Larsen TB, Lip GY (2013) Risk of stroke or systemic embolism in atrial fibrillation patients treated with warfarin: a systematic review and meta-analysis. Stroke 44(5):1329-1336. https://doi.org/10.1161/ STROKEAHA.113.000883

6. Olesen JB, Lip GY, Kamper AL, Hommel K, Køber L, Lane DA, Lindhardsen J, Gislason GH, Torp-Pedersen C (2012) Stroke and bleeding in atrial fibrillation with chronic kidney disease. N Engl J Med 367(7):625-635. https://doi.org/10.1056/NEJMoa1105594

7. ROCKET AF Study Investigators (2010) Rivaroxaban-once daily, oral, direct factor Xa inhibition compared with vitamin $\mathrm{K}$ antagonism for prevention of stroke and Embolism Trial in Atrial Fibrillation: rationale and design of the ROCKET AF study. Am Heart J 159(3):340-347.e341. https://doi.org/10.1016/j.ahj.2009.11.025

8. Pisters R, Lane DA, Nieuwlaat R, de Vos CB, Crijns HJ, Lip GY (2010) A novel user-friendly score (HAS-BLED) to assess 1-year risk of major bleeding in patients with atrial fibrillation: the Euro Heart Survey. Chest 138(5):1093-1100. https://doi.org/10.1378/ chest.10-0134

9. Lip GY, Nieuwlaat R, Pisters R, Lane DA, Crijns HJ (2010) Refining clinical risk stratification for predicting stroke and thromboembolism in atrial fibrillation using a novel risk factor-based approach: the Euro Heart Survey on atrial fibrillation. Chest 137(2):263-272. https://doi.org/10.1378/chest.09-1584

10. Fang MC, Go AS, Chang Y, Borowsky LH, Pomernacki NK, Udaltsova N, Singer DE (2011) A new risk scheme to predict warfarin-associated hemorrhage: the ATRIA (Anticoagulation and Risk Factors in Atrial Fibrillation) Study. J Am Coll Cardiol 58(4):395-401. https://doi.org/10.1016/j.jacc.2011.03.031

11. O'Brien EC, Simon DN, Thomas LE, Hylek EM, Gersh BJ, Ansell JE, Kowey PR, Mahaffey KW, Chang P, Fonarow GC, Pencina MJ, Piccini JP, Peterson ED (2015) The ORBIT bleeding score: a simple bedside score to assess bleeding risk in atrial fibrillation. Eur Heart J 36(46):3258-3264. https://doi.org/10.1093/eurheartj/ ehv476

12. Goodman SG, Wojdyla DM, Piccini JP, White HD, Paolini JF, Nessel CC, Berkowitz SD, Mahaffey KW, Patel MR, Sherwood MW, Becker RC, Halperin JL, Hacke W, Singer DE, Hankey GJ, Breithardt G, Fox KA, Califf RM, ROCKETAF Investigators (2014) Factors associated with major bleeding events: insights from the ROCKET AF trial (rivaroxaban once-daily oral direct factor Xa inhibition compared with vitamin $\mathrm{K}$ antagonism for prevention of stroke and embolism trial in atrial fibrillation). J Am Coll Cardiol 63(9):891-900. https://doi.org/10.1016/j. jacc.2013.11.013

13. Piccini JP, Stevens SR, Chang Y, Singer DE, Lokhnygina Y, Go AS, Patel MR, Mahaffey KW, Halperin JL, Breithardt G, Hankey GJ, Hacke W, Becker RC, Nessel CC, Fox KA, Califf RM, ROCKETAF Steering Committee Investigators (2013) Renal dysfunction as a predictor of stroke and systemic embolism in patients with nonvalvular atrial fibrillation: validation of the R(2)CHADS(2) index in the ROCKET AF (Rivaroxaban Once-daily, oral, direct factor Xa inhibition Compared with vitamin $\mathrm{K}$ antagonism for prevention of stroke and Embolism Trial in Atrial Fibrillation) and ATRIA (AnTicoagulation and Risk factors In Atrial fibrillation) study cohorts. Circulation 127(2):224-232. https://doi. org/10.1161/CIRCULATIONAHA.112.107128

14. Willmann S, Zhang L, Frede M, Kubitza D, Mueck W, Schmidt S, Solms A, Yan X, Garmann D (2018) Integrated population pharmacokinetic analysis of rivaroxaban across multiple patient populations. CPT Pharmacomet Syst Pharmacol 7(5):309-320. https://doi.org/10.1002/psp4.12288

15. Solms A, Frede M, Berkowitz SD, Hermanowski-Vosatka A, Kubitza D, Mueck W, Spiro TE, Willmann S, Yan X, Zhang L, Garmann D (2019) Enhancing the quality of rivaroxaban exposure estimates using prothrombin time in the absence of pharmacokinetic sampling. CPT Pharmacomet Syst Pharmacol 8(11):805814. https://doi.org/10.1002/psp4.12444

16. Nelson WW, Wang L, Baser O, Damaraju CV, Schein JR (2015) Out-of-range INR values and outcomes among new warfarin patients with non-valvular atrial fibrillation. Int J Clin Pharm 37(1):53-59. https://doi.org/10.1007/s11096-014-0038-3

17. Yin OQ, Tetsuya K, Miller R (2014) Edoxaban population pharmacokinetics and exposure-response analysis in patients with non-valvular atrial fibrillation. Eur J Clin Pharmacol 70(11):1339 1351. https://doi.org/10.1007/s00228-014-1736-4

18. Ruff CT, Giugliano RP, Braunwald E, Morrow DA, Murphy SA, Kuder JF, Deenadayalu N, Jarolim P, Betcher J, Shi M, Brown K, Patel I, Mercuri M, Antman EM (2015) Association between edoxaban dose, concentration, anti-factor Xa activity, and outcomes: an analysis of data from the randomised, double-blind ENGAGE AF-TIMI 48 trial. Lancet 385(9984):2288-2295. https ://doi.org/10.1016/S0140-6736(14)61943-7

19. Reilly PA, Lehr T, Haertter S, Connolly SJ, Yusuf S, Eikelboom JW, Ezekowitz MD, Nehmiz G, Wang S, Wallentin L, RE-LY Investigators (2014) The effect of dabigatran plasma concentrations and patient characteristics on the frequency of ischemic stroke and major bleeding in atrial fibrillation patients: the RE-LY trial (Randomized Evaluation of Long-Term Anticoagulation Therapy). J Am Coll Cardiol 63(4):321-328. https://doi. org/10.1016/j.jacc.2013.07.104

20. Bayer Healthcare AG (2019) Xarelto (rivaroxaban) prescribing information. https://www.janssenlabels.com/package-insert/ product-monograph/prescribing-information/XARELTO-pi.pdf. Accessed February 2020

21. Doherty JU, Gluckman TJ, Hucker WJ, Januzzi JL Jr, Ortel TL, Saxonhouse SJ, Spinler SA (2017) 2017 ACC Expert Consensus decision pathway for periprocedural management of anticoagulation in patients with nonvalvular atrial fibrillation: a report of the American College of Cardiology Clinical Expert Consensus Document Task Force. J Am Coll Cardiol 69(7):871-898. https ://doi.org/10.1016/j.jacc.2016.11.024

22. Erdoes G, De Arroyabe BMP, Bolliger D, Ahmed AB, Koster A, Agarwal S, Boer C, von Heymann C (2018) International consensus statement on the peri-operative management of direct oral anticoagulants in cardiac surgery. Anaesthesia 73(12):1535-1545. https://doi.org/10.1111/anae.14425

23. Girgis IG, Patel MR, Peters GR, Moore KT, Mahaffey KW, Nessel CC, Halperin JL, Califf RM, Fox KA, Becker RC (2014) Population pharmacokinetics and pharmacodynamics of rivaroxaban in patients with non-valvular atrial fibrillation: results from ROCKET AF. J Clin Pharmacol 54(8):917-927. https://doi. org/10.1002/jcph.288

24. Schulman S, Kearon C, Subcommittee on Control of Anticoagulation of the Scientific Standardization Committee of the International Society on Thrombosis, and Haemostasis (2005) Definition of major bleeding in clinical investigations of antihemostatic medicinal products in non-surgical patients. J Thromb Haemost 3(4):692-694. https://doi.org/10.1111/j.1538-7836.2005.01204.x

Publisher's Note Springer Nature remains neutral with regard to jurisdictional claims in published maps and institutional affiliations. 